\title{
Corporate Financial Disclosure In Nigerian Deposit Money Banks
}

\author{
Thomas D. Ayodele, PhD, ACIB \\ Department of Financial Studies \\ Redeemer's University, Ede, Osun state, Nigeria. \\ Taofeek S. Afolabi \\ Department of Financial Studies \\ Redeemer's University, Ede, Osun state, Nigeria.
}

\begin{abstract}
The study examined the impact of corporate financial disclosure on the performance of Nigerian Deposit Money banks. It evaluated the extent to which Nigerian Deposit Money banks complied with the financial disclosure requirements as given by the monetary authorities. Primary data collected through questionnaire were used for the study. Out of 120 copies of questionnaire served on respondents, 100 copies were recovered and used for the analysis of the study. The analytical tools used for the study are the t-test and the Analysis of variance (ANOVA). From the hypotheses tested, the results show that corporate financial disclosure has a significant influence on the banks' stability and performance in the Nigerian financial sector. Therefore, the study concludes that the corporate disclosure of financial reporting practices by banks in general will enable them to work towards improving and managing their non-performing loans effectively and efficiently for stability and hence better performance. It was therefore recommended among others that efforts should be geared towards improved corporate financial disclosure among money Deposit Money banks in Nigeria and mandatory compliance with the code of corporate governance and effective legal framework which specifies the rights and obligations of banks, it's directors and shareholders.
\end{abstract}

Keywords: Financial disclosure, Accounting standard, Corporate governance, Financial sector, Non-performing loans

\section{INTRODUCTION}

The disclosure principle in Accounting requires that financial statements present the most useful amount of relevant information that is necessary in order not to be misleading. The process of full disclosure has to do with ensuring the integrity of data in the rendition of reports to the supervisory authority and the public in order to enable them ascertain the true financial position and performance of deposit money banks.

Developments in corporate businesses all over the world since the dramatic collapse of the Enron corporation, an American company, in 2001, and the subsequent dissolution of Authur Anderson, which was then one of the big five audit and accountancy partnership in the world, have put accounting and auditing profession under scrutiny (Adeyemi \& Asaolu, 2013). The failure was adjudged to be the biggest audit failure at the time. Coming closely on the heels of the scandal at Enron was the sudden collapse of WorldCom in 2002, another American company in telecommunication industry with over US $\$ 107$ billion in assets. Each of these corporate scandals was directly linked to accounting and auditing misinformation and failure. The above phenomena and the global and economic crunch have resulted to increased attention to improve and enforce financial reporting disclosure worldwide in order to reform 
the global economy. Nigeria has recently taken steps to align all corporate reports to the International Reporting Standards (IFRSs) as a means of enhancing full disclosure and strengthening stakeholder's confidence (Adeyemi \& Asaolu, 2013)

However, financial reports of Nigerian companies have been found to be deficient over time (Adeyemi, 2006; Nzekwe, 2009), in the sense that they lack vital information that will enable stakeholders make informed decisions. Apart from the studies conducted by the World bank (2004), disclosure practices by Nigerian companies had been empirically investigated by Okike (2007), Adeyemi (2006), Ofoegbu and Okoye (2006). Their observations were quite similar in that they all found the Nigerian corporate financial reporting practices to be deficient. None of these earlier works was specifically devoted to the impact of corporate financial disclosure on the stability and performance of Nigerian Deposit Money Banks which this paper is out to address.

\section{The Concept of Full Financial disclosure}

\section{CONCEPTUAL FRAMEWORK AND LITERATURE REVIEW}

Soludo (2004) defines full disclosure requirements as the mandatory financial, operational and management information which financial institutions are required to disclose in the rendition of their periodic returns to the regulatory authorities and public. The concept of full disclosure is broad in scope. For a bank, it refers to the quality and quantity of public information on a bank's risk profile and to the timing of its disclosure, including the banks past and current decisions and actions as well as its plans for the future. The transparency of the banking sector as a whole includes public information on bank regulations and on safety net operations of the Central Bank (Soludo, 2008 and Oluyemi, 2006).

The objectives of introducing the full disclosure requirements are essentially to provide economic agents (depositors and investors) and other stakeholders with appropriate information to assist them in evaluating the financial positions and performances of banks and to enable them obtain better understanding of unique characteristics of operations of banks. The provision of adequate information enhances the integrity of banks and reduces the reputational risks that could jeopardize the confidence and patronage by their customers (Soludo, 2008).

Shaw (2003) also noted that provision of adequate information will also help to reduce market uncertainty and limit the risk of unwarranted contagion, thereby promoting market discipline and strengthening the banks in playing their intermediation role in the economy effectively.

According to Ghofar and Saraswati (2008), investors in most cases are too dependent on the quality of financial statements disclosure. Therefore Shaw (2003) opined that disclosure should be able to reduce asymmetric information between management and other stakeholders, especially investors and lenders. Asymmetric information occurs because management has more information and more authority to choose accounting procedures (Milne 2002; Oyerogba, 2014). It means that disclosure is expected to improve the effectiveness of communication between companies and their stakeholders (Verrecchia, 1999; Archambault \& Archambault, 2003).

\section{Corporate Financial Disclosure and Bank's Stability and Performance}

Corporate stability deals with the measurement of the success of management in creating value for the corporation. It relates to the way and manner in which financial resources available to organizations are judiciously used to achieve the overall corporate objectives of the organizations concerned (Shaw, 2003). This in turn keeps the organizations in business and 
create prospect for future opportunities. According to Sobodu and Akiode (1998), there is a consensus in the literature that management quality is the ultimate determinant of a bank's long term profitability and survival which are invariably a function of how effectively resources are used and how financing choices are prudently made. They observed that policymakers, economists and monetary authorities recognize that the ability of banks to achieve the desired results of continuous profitability and long term stability and to continue to play the role earmarked for them depends not only on the existence of an enabling regulatory environment and the number of operating banks but more importantly on their performance from one financial year to the other. Therefore, the more the number of operating banks that are resistant to adverse financial conditions of a country, the better for monetary policy and ultimately the economy.

As pointed out by Adeyemi and Asaolu (2013), the performance of banks attracts considerable attention from bank regulators and monetary authorities because they deal with liquid asset which can easily trigger the economy when misappropriated, and because banks occupy a delicate position in the economic equation of any country such that their performance, either good or bad, invariably affects the economy of the country. Based on this, banks in the economy are being compelled to disclose heir periodic returns and affairs to the regulatory authorities and public. This process has to do with ensuring the integrity of data in the rendition of reports to the supervisory authority and the public in order to enable them ascertain the true financial position and performance of the banks (Soludo, 2008).

\section{Corporate Financial Disclosure in Nigeria}

It has been observed that there is a high level of disclosure relating to balance sheet, historical items and valuation methods among Nigerian listed companies. However, there are apparent weaknesses in status data, social reporting, income statement items and projections (Oyerogba, 2014). Okike (2007) investigated the corporate reporting practice in Nigeria and discovered that it was weak and that accounting reports were found deficient because they lack vital information. Ofoegbu and Okoye (2006) also investigated the extent to which statement of Accounting standards are compiled within Nigeria by using a sample of seven standards (SAS 3, 7, 8, 11, 18 and 19) conveniently chosen. After analyzing the annual reports of 41 companies publicly quoted at the Nigerian Stock Exchange, it was discovered that there is a mixed result of compliance with disclosure requirements. Full compliance $(100 \%)$ was recorded for items such as; bases for determining book value of assets, cash flow presentations, disclosure of various forms of tax and movements of taxes and assets during the year. Partial compliance which ranges from $2 \%$ to $90 \%$ was recorded for items such as frequency of revaluation policy, amount of foreign exchange gain or loss, maturity profile of risk assets of banks and commission paid or received.

Adeyemi (2006) also considered SAS 1 to SAS 21 and using a sample of 96 listed companies with the year end between 2003 and 2004, he empirically determined that there is a relationship between corporate financial disclosure and some companies' characteristics outside profitability.

\section{METHODOLOGY}

This research work adopts a survey research method. Five banks were randomly selected from the current 22 Deposit Money Banks in the Nigerian financial system. Questionnaires were served on 24 managerial/senior staff members of each of the banks making a total of 120, out of which 100 were recovered for analysis. The received questionnaires cut across the banks surveyed fairly. 


\section{DATA PRESENTATION AND ANALYSIS}

The primary data collected from respondents were analyzed statistically by the use of one-way ANOVA and t-test, and the formulated hypotheses were tested as follows.

Hypothesis 1: There is no significant relationship between corporate financial disclosure and stability of banks in Nigeria.

Table 1: The responses on whether there is a significant relationship between corporate financial disclosure and banks' stability.

\begin{tabular}{|l|c|c|c|c|}
\hline Responses & Frequency & Percent & $\begin{array}{l}\text { valid } \\
\text { percent }\end{array}$ & $\begin{array}{l}\text { Cumulative } \\
\text { percent }\end{array}$ \\
\hline Strongly Agree & 32 & 32.0 & 32.0 & 32.0 \\
\hline Agree & 55 & 55.0 & 55.0 & 87.0 \\
\hline Disagree & 10 & 10.0 & 10.0 & 97.0 \\
\hline Strongly Disagree & 3 & 3.0 & 3.0 & 100.0 \\
\hline Total & $\mathbf{1 0 0}$ & $\mathbf{1 0 0}$ & $\mathbf{1 0 0}$ & \\
\hline
\end{tabular}

Source: Field survey, 2017.

Table 2: ANOVA

\begin{tabular}{|c|c|c|c|c|c|}
\hline Model & $\begin{array}{l}\text { Sum of } \\
\text { squares }\end{array}$ & df & $\begin{array}{l}\text { mean } \\
\text { square }\end{array}$ & F & Sig. \\
\hline 1. $\begin{array}{c}\text { Regression } \\
\text { Residual }\end{array}$ & 24.808 & 1 & 24.808 & 72.288 & 0.000 \\
\hline Total & $\mathbf{5 8 . 4 4}$ & $\mathbf{9 9}$ & & & \\
\hline
\end{tabular}

Source: Authors' computation, SPSS 20, November 2017.

From table 1 above, it can be deduced that out of 100 managerial/senior staff members of the banks surveyed, 32 of them (32\%) strongly agreed that there is a significant relationship between corporate financial disclosure and their banks' performance. 55 also agreed to the assertion forming 55\% of the respondents. 10 and 3 disagreed and strongly disagreed respectively. It can be concluded that the assertion is very true going by the responses.

Based on the ANOVA table above, the F-ratio value of 72.288 is far greater than the F-critical value of 3.938. This shows that the test is statistically significant at 0.01 and so the null hypothesis is rejected and the alternative one is accepted. Therefore, we can conclude that there is a significant relationship between corporate financial disclosure and stability of Deposit Money Banks in Nigeria.

Hypothesis 2: There is no significant relationship between corporate financial disclosure policy and corporate performance of Nigerian Deposit Money Banks. 
Table 3: Whether the banks strictly followed the stipulated corporate financial disclosure policy to improve their corporate performance.

\begin{tabular}{|l|c|c|l|l|}
\hline Responses & Frequency & Percent & $\begin{array}{l}\text { valid } \\
\text { percent }\end{array}$ & $\begin{array}{l}\text { Cumulative } \\
\text { percent }\end{array}$ \\
\hline Strongly Agree & 42 & 42.0 & 42.0 & 42.0 \\
\hline Agree & 44 & 44.0 & 44.0 & 86.0 \\
\hline Disagree & 12 & 12.0 & 12.0 & 98.0 \\
\hline Strongly Disagree & 2 & 2.0 & 2.0 & 100.0 \\
\hline Total & $\mathbf{1 0 0}$ & $\mathbf{1 0 0}$ & $\mathbf{1 0 0}$ & \\
\hline
\end{tabular}

Source: Field survey, 2017.

Table 4: One Sample Test

\begin{tabular}{|c|c|c|c|c|c|c|}
\hline & \multicolumn{6}{|c|}{ Test value $=0$} \\
\hline & \multirow[t]{2}{*}{$\mathrm{t}$} & \multirow[t]{2}{*}{$\mathrm{df}$} & \multirow{2}{*}{$\begin{array}{c}\text { sig. } \\
\text { (2-tailed) }\end{array}$} & \multirow{2}{*}{$\begin{array}{c}\text { Mean } \\
\text { Difference }\end{array}$} & \multicolumn{2}{|c|}{$\begin{array}{l}95 \% \\
\text { Confidence } \\
\text { Interval of } \\
\text { Diff. }\end{array}$} \\
\hline & & & & & Lower & Upper \\
\hline $\begin{array}{l}\text { Your bank strictly followed the } \\
\text { stipulated corporate financial } \\
\text { disclosure policy to improve its } \\
\text { corporate performance. }\end{array}$ & 48.325 & 99 & 0.000 & 3.26000 & 3.1725 & 3.3475 \\
\hline
\end{tabular}

Source: Authors' computation, SPSS 20, November 2017.

From the data presented in table $3,42 \%$ of the respondents strongly agreed that adherence to stipulated corporate financial disclosure policy improves corporate performance of their banks. Another 44\% lent their support to the statement. Only 12 respondents disagreed and two (2) respondents strongly disagreed with the assertion. It can therefore be concluded that adherence to a stipulated corporate financial disclosure policy promotes and improves corporate performance of banks in Nigeria.

Also from table 4, the t-test value is high at 48.325 which is greater than the t-test critical value of 1.984. This indicates that the test is statistically significant at 0.01 . It therefore depicts that the null hypothesis is rejected and the alternative hypothesis be accepted, meaning that, there is a significant relationship between corporate financial disclosure policy and corporate performance of Nigerian Deposit Money Banks.

\section{CONCLUSION AND RECOMMENDATION}

The paper investigated the impact of corporate financial disclosure on the stability and performance of Nigerian Deposit Money Banks. It was discovered that corporate financial disclosure plays a vital role in bank's stability and performance in the Nigerian context. This is shown in the two hypotheses where it was concluded that there is a significant relationship between corporate financial disclosure and banks' stability on one hand and a significant relationship between corporate financial disclosure and corporate performance of Nigerian Deposit Money Banks on the other hand.

Based on the above, it is therefore recommended that though there is corporate financial disclosure put in place by the Nigerian Deposit Money Banks, efforts should be geared towards enforcing it's implementation and compliance amongst them, so that sharp practices by the managers and board of directors can be nipped in the bud. This will help a long way in boosting 
the confidence reposed in Nigerian banks by customers, thereby stabilizing the banking sector of the country more and making them more competitive in the committee of global banks.

\section{References}

Adeyemi, A. and Asaolu, T. (2013). An Empirical Investigation of the Financial Reporting Practices and Banks' Stability in Nigeria. Arabian Journal of Business and Management Review, 2 (5), 157 - 180.

Adeyemi, S. B. (2006). Impact of Accounting Standards on Financial Reporting in Nigeria. Unpublished PhD thesis, University of Lagos.

Archambault, J. J. and Archambault, M. E. (2003). A Multinational Test of Determinants of Corporate Disclosure. The International Journal of Accounting, 38, 173 - 194.

Ghofar, A. and Sarasiwati, E. (2008). Problems in Financial Reporting: The Analysis of Quality of Disclosure and the Measurement System of the Traditional Accounting. Retrieved from http://www.indonesiauniversity.edu.in/on November 28, 2017.

Milne, M. J. (2002). Positive Accounting Theory, Political Cost and Social Disclosure Analysis: A Critical Look. Critical Perspectives on Accounting, 13, 369 -395.

Nzekwe, S. (2009). “ANAN Commends Senate on Financial Reporting Council Bill”, The Guardian. Retrieved from www.ngrguardiannews.com/.../indexn3_html, accessed October 23, 2017.

Ofoegbu, G. and Okoye, E. (2006). The Relevance of Accounting and Auditing Standards in Corporate Financial Reporting in Nigeria: Emphasis on Compliance. The Nigerian Accountant, 39 (4), 45 - 53.

Okike, E. N. (2007). Corporate Governance in Nigeria: The Status Quo Corporate Governance. An International Review, 15 (2), 179 - 193.

Oluyemi, S. A. (2006). Banking Sector Reforms and the Imperative of Good Corporate Governance, in the Nigerian Banking System. NDIC Quarterly Review.

Oyerogba, E. O. (2014). Risk Disclosure in the Published Financial Statements and Firm Performance: Evidence from the Nigeria Listed Companies. Journal of Economics and Sustainable Development, 5 (8).

Shaw, K. W. (2003). Corporate Disclosure Quality, Earnings' Smoothing and Earnings' Timeliness. Journal of Business Research, 56, 1043 - 1050.

Sobodu, O. O. and Akiode, P. O. (1998). Bank Performance and Supervision in Nigeria: Analyzing the Transition to a Deregulated Economy. AERC Research paper 71, p. 23

Soludo, C. (2004). Consolidating the Nigerian Banking Industry to meet the Development Challenges of the $21^{\text {st }}$ Century. BIS Review 43, European Journal of Social Sciences, 15 (4)

Soludu, C. (2008). The Unfinished Revolution in the Banking System. (Online) Presentation at the University of Agriculture Abeokuta on March 18, 2008 by the CBN Governor. Available at

http://www.org/ONT/SPEECHES/2008/Govadd 26-3-08.pdf (accessed June 2, 2008).

Verrecchia, R. E. (1999). Disclosure and the Cost of Capital: A Discussion. Journal of Accounting and Economics, 26, $271-283$.

World Bank (2004). Report on the Observance of Standards and Codes (ROSC) in Nigeria, Accounting and Auditing. Retrieved from http://www.worldbank.org/ifa/rosc_aa_nga.pdf, accessed June 26, 2017. 